Душан М. Стаменковић ${ }^{1}$

Универзитет у Нишу

Филозофски факултет

Департман за англистику²

Ана В. Коцић Станковић

Универзитет у Нишу

Филозофски факултет

Департман за англистику
Оригинални научни рад

УДК 821.111(73).09-31 Набоков В.

Примљен: 11. октобра 2020.

Прихваћен: 30. октобра 2020.

https://doi.org/10.46630/phm.13.2021.27

\title{
ЗНАЧЕЊЕ И СИМБОЛИКА ИМЕНА ЛИКОВА У РОМАНУ БЛЕДА ВАТРА
}

\begin{abstract}
Рад представља покушај читања Набоковљевог романа Бледа ватра у светлу књижевне ономастике при чему се посебна пажња посвећује именовању ликова. Теоријски оквир ослања се на увиде разних поддисциплина ономастике, од хронолошког приказа развоја дисциплине, преко најважнијих одлика књижевне ономастике као релативно нове академске дисциплине. У том смислу, рад покушава да примени овај приступ на читање књижевног дела. Аналитички део рада бави се именима четири главна лика у роману, односно, њиховим митолошким, значењским, симболичким и иронијским димензијама и потенцијалним тумачењима која из такве анализе проистичу. Једна од кључних претпоставки рада је да се значење, како имена ликова тако и самог романа, открива у интеракцији између различитих симболичких значења и импликација, кроз својеврсну „игру” поетске истине и лажи. Закључак је да Набоков вешто користи значења и симболику имена како би их уградио у структуру Бледе ватре и, на неки начин, додатно закомпликовао већ ионако довољно комплексан однос стварности и маште и чудне споне паралелних интерпретација књижевног дела и света око нас.
\end{abstract}

Клучне речи: Ономастика, именовање, име, презиме, антропоним, Набоков, Бледа ватра

1 dusan.stamenkovic@filfak.ni.ac.rs

2 Припремљено у оквиру пројекта Иновације у настави и истраживаюа у области англистичке лингвистике и англоамеричке книжевности и културе, који се изводи на Филозофском факултету Универзитета у Нишу (бр. 360/1-16-1-01). Ово истраживање финансијски је подржало Министарство просвете, науке и технолошког развоја Републике Србије. 


\section{Увод}

Ономастичка питања, сконцентрисана око проблема и тема везаних за имена и процес именовања представљају једно од најранијих питања у студијама језика, иако се сам термин ономастика јавио знатно касније, па се сама дисциплина сматра младом (HAF 2016). Њени корени су свакако смештени још у античко време и најчешће се везују за групу питања која се разматрају у Платоновом Кратилу (PALMER 1976, KOUTS 2006). За фокус у овом раду нарочито је важна поддисциплина антропоономастике, која се фокусира како на историјске обрасце именовања и употребе имена, тако и на синхронијске проблеме везане за давање имена, при чему се нарочито у првом случају ослања у доброј мери и на етимологију (HAF 2016), али и на друге елементе који потичу из значења имена и његовог положаја у култури и историји (BAGBI I SIGALOV 1987). Једна од још новијих поддисциплина ономастике је књижевна ономастика и она обухвата различит број приступа (HAF 2016), али у њима често срећемо позиве да се проблему имена у књижевности приступа систематично (SMIT 2016). Као основна средства у овој врсти ономастике за анализу наводе се како елементи етимологије, као и звучне и семантичке асоцијације, тако и други могући језички и текстуални елементи који могу да имају утицај на имена и именовање (KAVIL 2016). Некад се приступи ослањају и на каузалну теорију именовања (KRIPKE 1980) у којој се имена ликова сагледавају кроз повезивање са оригиналним референтом (MILENKOVIĆ I MLADENOVIĆ 2016). Са становишта формалне анализе књижевности, именовање ликова представља важан елемент карактеризације ликова, а књижевна ономастика наглашава и семиотичке везе између имена ликова и теме дела које се појединим оквирима анализе књижевног дела расветљавају (SMIT 2016: 307). У нашој студији се на систематичан начин приступа процесу именовања ликова у Набоковљевој Бледој ватри, имајући пре свега у виду значај који се експлицитно даје именима и проблему значења у самом роману. Надамо се да овакав приступ може да буде прилог дисциплини књижевне ономастике на нашим просторима. Бледа ватра је као извор одабрана из једноставног разлога, а то је важност самих имена за интерпретацију догађаја, ставова, мисли и осталих елемената кључних за одгонетање порука које Владимир Набоков настоји да пренесе читаоцима.

На почетку свог есеја „Игре на лексичким пољима у Набоковљевој Бледој ватри", Карл Ајхелбергер каже да Бледа ватра Владимира Набокова захтева од читаоца „не само да буде креативан, него и да буде спреман да учествује у низу компликованих и сложених игара које су уткане у структуру романа" (AJHELBERGER 1984: 176). Једна од тих игара 
је сигурно и ономастичка игра са именима која Набоков бира за своје ликове. У Бледој ватри читаоци се сусрећу са великим бројем изазова, они морају да разграниче нивое реалности и маште, затим да увиде тачке где се ти нивои преплићу и поклапају; пред читаоцима је и питање истине и њеног постојања. Набоков гради читав један сплет загонетки, које Мери Макарти, амерички писац и критичар, назива сложеним механизмом којим се постепено открива игра речима као и динамични однос између аутора и критичара/читаоца (MAKARTI 1962: 21). Набоков нас лишава могућности да одредимо образац по коме он именује своје ликове - код неких имена и презимена видимо дозу ироније, јер их носе ликови чија је карактеризација потпуно супротна њиховом значењу, нека од њих потпуно одговарају ономе што описују, има оних која су негде између ироније и озбиљности, тј. где се ово двоје преплићу. Нека од имена се могу применити не само на одређени лик, већ на шири опсег повезаних елемената. Овај рад представља ономастичку анализу која је у контесту самог романа један покушај да се у именима и презименима четири главна лика у овом роману препознају потенцијална симболичка значења.

\section{Методолошки поступак}

Ономастички приступ ограничен је на антропониме везане за главне ликове, чија се имена и презимена (изузимајући она најопштија попут имена Џон) дубински анализирају обухватајући елементе етимологије, историје и митологије, енкциклопедијско и речничко знање, као делове самог романа и његов контекст. На тај начин се расветљава и комплексна мрежа која се јавља у интеракцији ликова, укључујући и њихова имена.

\section{Џон Шејд (John Shade)}

Име песника, аутора песме Бледа Ватра је Џон Шејд, а овај део анализе се бави његовим презименом. Оксфордски речник енглеског језика (OED 2012) реч shade дефинише на више начина, од којих су за анализу симболике ове речи у овом контексту најбитнији следећи:

- делимична тама; одсуство потпуног осветљења; нарочито затамњеност проузрокована тиме што мање или више непрозиран објекат спречава продор зрака сунчеве светлости или светлости неког другог светлећег тела,

- сенка,

- нејасност,

- тамни одраз на некој подлози,

- нестварна слика нечег стварног,

- видљива, али недодирљива слика мртваца, дух. 
(у множини - the shades/shades)

- тама ноћи,

- тама која се шири након заласка сунца,

- тмина пакла; место где живе мртваци, Хад.

Значења ове речи из обе колоне (било да се ради о употреби у једнини или множини) могу да се поделе на два већа дела - једна група значења се односи на недостатак светлости или замагљеност вида (сенка, тама, нејасност), док се друга група односи на загробни свет, тј. свет покојника и њихових духова. На почетку своје песме, Шејд сам себе назива сенком:

„Ја бејах сенка свилорепе убијене

лажним плаветнилом у прозорском окну. ${ }^{3}$ (NABOKOV 1962/1988:

23)

Песник затим на неколико места у песми помиње сенке, таму, и ноћ, па се чини да је песма овенчана тамом, вероватно услед догађаја који су зацрнили песников живот: „А потом црна ноћ. Тај мрак беше узвишен" (NABOKOV 1962/1988: 27). Сенка се може тумачити не само као нешто што налазимо у самој песми, већ и као део целог сплета околности под којима песма настаје, у којима се сачињавају коментари на њу и под којима бива издата. Сенку можемо повезати са комплексним проблемом улоге аутора и нашим трагањем за оним што се може означити као стварност (или истина). Сенка у овом погледу може да представља збуњеност самог аутора и замагљеност његовог погледа на свет, као и фактор који збуњује читаоце, што може да буде и Набоковљева игра.

Детаљи онога што се стварно збило и онога што је део песникове маште се постепено мешају, па то на читаоца заиста оставља утисак пролажења кроз маглу у којој сам мора да тражи истину, уколико она уопште постоји. Посао читаоца додатно отежава "помоћ" коју добија од Кинбота, па се сенка практично интензивира услед његових коментара, а једини механизам да се разоткрије оно преко чега ова сенка бачена је у самом читаоцу. Треба поменути и да реч „shady” означава онога коме се не може веровати, па се асоцијација на непоузданог наратора намеће као још једно потенцијално објашњење. Другим речима, на читаоцу је да дешифрује фрагменте значења како би дошао/ла до песникове истине. Ту је још и парадоксална чињеница да Шејда, у Кинботовим очима, убија Градус, који је члан организације која се зове управо Сенке. Уколико реч shade дефинишемо као нејасност, постоји низ релевантних елемената које можемо одредити тим значењем - још једном, нејасно је шта је ствар-

3 У оригиналу: „I was the shadow of the waxwing slain / By the false azure in the windowpane” 
но, а шта измишљено, нејасне су границе Кинботовог и Шејдовог света, као, вероватно, и сами мотиви који леже како иза песме, тако и иза њеног коментара ${ }^{4}$.

Уколико пак реч shade вежемо за свет умрлих и њихових духова, пуно је елемената који Шејдове мисаоне процесе и његову песму повезују са овим значењем. Пре свега, чини се да је цели његов живот, који он настоји да у сликама опише у својој Бледој ватри, од раног детињства, па све до дана старости обележен смрћу њему драгих особа. Мотив смрти креће од смрти његових родитеља у време док је још био дете, наставља се смрћу тетке Мод, а све кулминира самоубиством његове ћерке Хејзл. Име Хејзл (Hazel), које подсећа на енглеску реч „haze” (измаглица) можемо схватити као додатни наговештај да слика коју добијамо није најјаснија. За живота, сама Хејзл испољава велико интересовање за феномене везане за загробни живот - она истражује духове, полтергајстовске сметње, стругање и кружиће светлости које наводно производе духови („шеснаестогодишња Хејзл [je] била уплетена у неке запањујуће »психокинетичке« манифестације које су трајале готово месец дана. У почетку, да се закључити, полтергајст је намеравао да прожме немир идентитетом тетке Мод која је управо била умрла”, NABOKOV 1962/1988: 126).

Сам Шејд се ограђује од вере у загробни живот:

„Тај неукусни подухват на неки начин ми је помогао.

Научио сам шта треба да занемарим приликом прегледа

Амбиса смрти. А када смо изгубили дете

Знао сам да неће бити ничега: никакав самозвани

Дух неће такнути дирке од сувог дрвета"5 (NABOKOV 1962/1988: 43)

Насупрот овоме, он ипак макар подсвесно тежи да одржи контакт са оним светом, да размишља о смрти и држи је у својој близини. То

4 Брајан Бојд, у својој књизи Набоковљева Бледа Ватра: Чаролија уметничког отркића (BOJD 2001), напомиње да су се последњих година појавиле идеје да је један те исти човек аутор свих интегралних делова Бледе ватре (предговора, песме, коментара и регистра), а да онај други, песник или критичар, уопште не постоји. Самим тим постаје нејасан и сам аутор - неки тврде да је то Џон Шејд (Ендру Филд, Генади Барабтарло, Крис Акерли, Сергеј Илин,...), док други део јавности тврди да је Чарлс Кинбот аутор свих делова (Пејџ Стегнер, Пека Тами, Чарлс Никол,...). Наравно, највећи број је оних који још увек сматрају да су то две одвојене особе, што сенку над Бледом ватром чини још већом.

5 У оригиналу: „That tasteless venture helped me in a way.

I learnt what to ignore in my survey

Of death's abyss. And when we lost our child

I knew there would be nothing: no self-styled

Spirit would touch a keyboard of dry wood" 
можемо да видимо, између осталог, и у чињеници да он чува играчку на навијање, која му, бар по Кинботовим речима, служи као сећање на смрт, јер је као мали, у присуству те лутке доживео несвестицу, коју вероватно сматра својим првим сусретом са смрћу:

„Захваљујући срећном случају, видео сам је! [...] Радо ме је повео у подрум, али пошто је мало прочепркао по гомилама прашњавих књига и часописа, рекао је да ће покушати да их пронађе неком другом приликом. Тада сам је видео на једној полици, између свећњака и будилника без казаљки. Он, помисливши да бих ја могао помислити како је припадала његовој мртвој кћерки, брзо објасни да је стара колико и он. Дечак је био мали црнац од обојеног лима, с рупицом за кључић са стране и готово без ширине, јер се састојао од два мање-више спојена профила, а његове тачке биле су скроз искривљене и поломљене. Он рече, бришући прашину с рукава, да је чува као неку врсту мементо морија ${ }^{23}$ - једног дана, у детињству, док се играо том играчком, доживео је необичан напад несвестице ${ }^{6}$.

досл. Сећај се смрти, сети се да мораш умрети; све што подсећа на смрт (лат.) (Прев.)” (NABOKOV 1962/1988: 105)

Велики део Шејдове песме је посвећен управо смрти, њени редови су пуни духова из прошлости, а сам песник бива ангажован од стране једног института да месец дана држи предавања управо о смрти. У другом певању он чак сам каже да је цели свој живот посветио борби „против гнусног, недоступног амбиса” (NABOKOV 1962/1988: 29). Бојд сматра да Шејд покушава да разуме живот који је са свих страна окружен смрћу (BOJD 2001: 25). Све у свему, Шејдово презиме, са свим својим потенцијалним значењима и интерпретацијама, у мањој или већој мери осликава атмосферу бар дела живота и стваралаштва њега као песника.

6 У оригиналу: „By a stroke of luck I have seen it! [...] He willingly took me down into the basement but after rummaging among piles of dusty books and magazines, said he would try to find them some other time. It was then that I saw it on a shelf, between a candlestick and a handless alarm clock. He, thinking I might think it had belonged to his dead daughter, hastily explained it was as old as he. The boy was a little Negro of painted tin with a keyhole in his side and no breadth to speak of, just consisting of two more or less fused profiles, and his wheelbarrow was now all bent and broken. He said, brushing the dust off his sleeves, that he kept it as a kind of memento mori - he had had a strange fainting fit one day in his childhood while playing with that toy." 


\section{Сибил (Sybil)}

Име песникове жене Сибил (Sybil) jе изведено од назива који је у митологији Грчке, Рима и Блиског Истока означавао сибилу, пророчицу $(s i b y l)$. Реч је у енглески језик ушла преко грчког и латинског. Сибила је у грчкој и римској митологији жена којој је бог Аполон даривао моћ прорицања ${ }^{7}$.

Чини се да има и сличности и разлика између античких сибила и песникове супруге, али делује да Набоков ово име бира са дозом ироније. Видимо да Кинбот верује у Бога на традиционалан начин. Он Сибил, због тога што је одбила да се повинује некој одређеној цркви, у једном тренутку заиста повезује са паганском (или, како он каже, полупаганском) традицијом:

„Сибил Шејд потиче из католичке породице, али је од раног девојаштва, како ми је сама рекла, развијала »властиту религију« - што је обично синоним, у најбољем случају, за млаку приврженост некој полупаганској секти или, у најгорем случају, за лабави атеизам. Она је одвукла свог супруга не само од епископске цркве његових предака, него и од свих облика сакраменталног богослужења." (NABOKOV 1962/1988: 169-170)

Видимо да Кинбот сматра да Сибил на неки начин одвлачи Џона од конвенционалног хришћанства, што он карактерише као приврженост паганству или атеизму. Сибил успева да надживи све остале главне ликове овог романа, и на тај начин бива још више окружена смрћу него што је то био њен покојни супруг, а можемо чак претпоставити да услед губитка две најдраже особе, као и услед њене вере у загробни живот, она чека дан када ће им се придружити. У свим осталим погледима, Сибил је практично супротност митским сибилама - она нема способност да предвиди трагедије које се дешавају њеном супругу и њој, нити да их на

7 Сибиле су живеле у пећинама или близини потока и прорицале су док су биле у стању френетичног транса. У петом веку пре нове ере, Хераклит наводи: „Сибила, уз панични говор који казује о стварима којима се не сме подсмевати, без улепшавања и дотеривања, види хиљаду година унапред, надарена од бога." (HERAKLIT). Пророчанства сибила била су у форми грчког хексаметра и у писаном облику су се преносила с колена на колено. Прва сибила која се помиње у делима раних грчких писаца је еритрејска Херофила, која је прорекла Тројански рат, и тада се сматрало да је она једина сибила. Касније се број сибила увећао на десет, да би се на крају сибилом сматрала свака жена која је испољавала горенаведену способност.

8 У оригиналу: „Sybil Shade came from a Catholic family but since early girlhood developed, as she told me herself, "a religion of her own" - which is generally synonymous, at the best, with a half-hearted attachment to some half-heathen sect or, at the worst, with tepid atheism. She had weaned her husband not only from the Episcopal Church of his fathers, but from all forms of sacramental worship." 
било који начин предухитри и спречи. Старим Грцима су сибиле омогућавале да живот проживе боље, да их упозоре на смрт и припреме за живот после смрти. Сибил заиста чини Џонов живот бољим и срећнијим, али када је реч о смрти, она је ту немоћна. Његова жена чак нема ни способност да буде његова једина муза, јер он своју музу описује као нешто крајње неухватљиво:

„А моја чудна муза

Та мењачица облика, са мном је свуда,

У просторији за читање, у колима, и у мојој столици."9

(NABOKOV 1962/1988: 52)

Чини се да се оваквим именовањем лика читаоцу заправо иронијски сугерише да је лик у супротности за асоцијацијама које њено име буди. То је истовремено и део наративног поступка и карактеризације лика, а може се тумачити и као коментар на савремени свет у коме имена постепено губе своја митска значења и постају обичне ознаке које се користе у свакодневном животу.

Чарлс Кинбот/Всеслав Боткин/Чарлс II Гзавије Всеслав (Вољени) од Зембле (Charles Kinbote/Vseslav Botkin/Charles II Xavier Vseslav (the Beloved) of Zembla)

Презиме „отмичара” Шејдове песме је Кинбот. Делови презимена су кин (енг. породица, раса, крвно сродство) и бот (врста црва који напада живе организме), што можемо везати за Кинботово својеврсно паразитирање на Шејдовој песми. Ово презиме треба сагледати и као анаграм презимена Боткин везан за реч „bodkin”, што је назив за врсту оштрице на врху стреле. Презиме Боткин има и своје историјске референце, па тако Брајан Бојд (2001: 91) наводи тројицу Руса са истим презименом коју можемо довести у везу са Боткином из овог романа. Један од њих је Василиј Боткин, писац и преводилац, пријатељ Тургењева (чије се име у Бледој ватри јавља као део имена биљке - Helitropum turgenevi, NABOKOV 1962/1988: 76). Други је доктор Јевгениј Боткин, породични доктор цара Николе II, који је убијен заједно са царском породицом у Јекатеринбургу 1918. године (KING I VILSON 2003: 61). Трећа личност је С. Д. Боткин, један од најбитнијих активиста у монархистичким организацијама у Берлину двадесетих година (у коме је у то време било пуно руских емиграната). Његово деловање је било врло слично деловању

9 У оригиналу: „And that odd muse of mine,

My versipel, is with me everywhere,

In carrel and in car, and in my chair." 
Набоковљевог оца. Убијен је у једној од акција које су уследиле након револуције у Русији. Сам Кинбот покушава да се насилно дистанцира од презимена Боткин, тиме што без икакве потребе у коментар и регистар уводи ово име, па тако пише „Боткин, Б. амерички учењак руског порекла, 894; кинг-бот, ларва изумрле мушице која се некада развијала у мамутима и за коју се сматра да је убрзала њихов филогенетски крај, 247; творац ботекина, 71; бот, бућ, и ботелиј, трбушаст (рус.); боткин или бодкин, дански бодеж." (NABOKOV 1962/1988: 228); раније поменута повезаност са паразитирањем се апострофира и у овом делу регистра. У коментару стиха 894. он објашњава:

„Професор Пардон тада се обрати мени: »Био сам под утиском да сте се ви родили у Русији, и да је ваше име нека врста анаграма од Боткин? «

Кинбот: »Помешали сте ме с неком избеглицом из Нове Зембле« [саркастично наглашавајући »Нова«].

»Зар ми нисте ви рекли, Чарлсе, да кинбот значи краљо-убица на вашем језику? « упита мој драги Шејд.

"Да, онај ко уништава краља«, рекох (жудећи да објасним да је у неком смислу управо то краљ који потапа свој идентитет у огледалу изгнанства).

Шејд [обраћајући се немачком посетиоцу]: »Професор Кинбот је аутор значајне књиге о презименима. Верујем [мени] да постоји енглески превод?«

»Оксфорд, 1956«, одговорих."10 (NABOKOV 1962/1988: 203)

Очигледно је да је лако повезати Кинботов лик са делом његовог презимена бот, које означава врсту паразита. Сама Сибил Шејд даје Кинботу следеће епитете: „слоновски крпељ; кинг-сајз обад; мајмун од црва; монструозни паразит генија” (NABOKOV 1962/1988: 131). Може се лако уочити да се Кинбот у креативном смислу стварно понаша као

10 У оригиналу: „Professor Pardon now spoke to me: 'I was under the impression that you were born in Russia, and that your name was a kind of anagram of Botkin or Botkine?'

Kinbote: 'You are confusing me with some refugee from Nova Zembla [sarcastically stressing the 'Nova'].'

'Didn't you tell me, Charles, that kinbote means regicide in your language?' asked my dear Shade.

'Yes, a king's destroyer', I said (longing to explain that a king who sinks his identity in the mirror of exile

is in a sense just that).

Shade [addressing the German visitor]: 'Professor Kinbote is the author of a remarkable book on surnames. I believe [to me] there exists an English translation?'

'Oxford, 1956,' I replied.” 
паразит - он користи Шејдову песму како би пропагирао сопствене идеје и издао измишљену аутобиографију. Он не само да користи песму да промовише себе, него је на такав начин уједно и тешко скрнави, убеђујући људе да песма представља нешто са чим она практично нема никакве везе. Сибил Кинбота, баш из овог разлога зове још и Кингбот, па јој Шејд, мислећи да она то ради ненамерно, скреће пажњу: „Шаљем ти ово писмо авионом и енергично понављам адресу коју ти је Силвија дала: Др Ч. Кинбот, КИНБОТ (а не »Чарлс Кс. Кингбот«, како сте ти, или Силвија, написале; молим те, буди пажљивија - и интелигентнија)" (NABOKOV 1962/1988: 193). Кинботов коментар може се сматрати и метафоричком оштрицом (бодекин/бодкин), којом он сече и чупа делове песме, како би између њих уметнуо своје мисли. Ако о Бодкину говоримо као о особи уметнутој између друге две особе, то се наравно опет може односити на Кинбота, који (у мањој или већој мери) алтернира између краљевског себе и себе као особе која пише коментар, где се наводно труди да крије своју плаву крв, или како он то, у горе наведеном цитату објашњава, он је „краљ који потапа свој идентитет у огледалу изгнанства”. Његове везе са историјским личностима које су носиле презиме Боткин су очигледне - двојица од тројице су на неки начин везани за монархију и код њих се поново срећемо са егзилом и борбом са револуционарима. Један од њих је, као и Кинбот, књижевни аутор.

Јакоб Градус/Жак д’Аргус/Џек Дигри/Џек Греј/Џејмс де Греј (Jakob Gradus/Jacques d’Argus/Jack Degree/Jack Grey/James de Gray)

Убица песника Џона Шејда је Џек Греј, бегунац из Института за криминално поремећене особе:

„револвераш се представио као Џек Греј, без сталног места боравка, изузев ИЦИ-ја, Института за луде криминалце, ици, добро псето, што је наравно, требало да буде његова стална адреса, и одакле је, по мишљењу полиције, управо побегао."11 (NABOKOV 1962/1988: 222)

Кинбот признаје физичку сличност стварног човека и "његовог” измишљеног убице: „[Џек Греј] који је, признајем, мало наликовао на покојног Жака д’Аргуса (NABOKOV 1962/1988: 65). Овој особи он, у свом паралелном свету, додељује друга имена: Јакоб Градус, и додаје јој неколицину псеудонима - Жак д’Аргус (Jacques d’Argus), Џек Дигри (Jack Degree), Џек де Греј, (као и мање битни Виноградус и Лењинградус). Ова имена са собом носе одређена симболичка значења, битна за разумевање овог романа. Жак и Јакоб су верзије хебрејског имена Јаков (Ya'aqов), 11 У оригиналу: ,the gunman gave his name as Jack Grey, no fixed abode, except the Institute for the Criminal Insane, ici, good dog, which of course should have been his permanent address all along, and which the police thought he had just escaped from." 
док се Џек у англофоном свету најчешће везује за име Џон, али има и начина да се повеже са именом Јаков. Јаков је име фигуре из Старог Завета, родоначелника дванаест хебрејских племена и једног од главних ликова књиге Постања. Концепт који се често везује за Јакова јесу Лестве Јаковљеве - лестве које воде до раја и које је он једном приликом уснуо. Саме лестве се могу повезати и са његовим презименом, посебно са варијантама Дигри (Дегрее) и Градус. Реч degree у енглеском означава степен, односно ступањ, што је директно повезано са концептом пењања уз, односно силажења низ лестве. Латинска реч градус има исто значење - степен, ступањ, корак (исто значење има и на руском језику, NABOKOV 1962/1988: 235). Gradus ce среће у фрази Gradus ad Parnassum (Кораци ка Парнасу), што је назив за врсту речника или уџбеника који је намењен да служи као помоћ у писању стихова на латинском или грчком, или назив за књигу са музичким вежбањима. Парнас је планина на којој су боравиле музе и на коју су уметници из грчке митологије одлазили како би нашли инспирацију.

Јакоб Градус је, у Набоковљевој режији, чини се, потпуна супротност библијског Јакова - он није симбол живота, зачећа и будућности, већ, као убица Џона Шејда, симбол смрти и краја. Може се иронично схватити да лестве из његовог презимена свакако воде Џона Шејда ка небу, јер га лишава живота, али слика није ни мало светла као она из Јаковљевог сна - у Градусовом чину нема ничег позитивног, светлог и обећавајућег, његов чин је суров и представља крај једног живота и једне песме. Песма нас води и ка тумачењу фразе Gradus ad Parnassum у овом контексту. Сходно Набоковљевој игри речима, слика је и овде потпуно изврнута - Градусове лестве Шејда не воде до Парнаса, не доносе му инспирацију, већ нагло прекидају његову песничку каријеру и самим тим раде против уметности и против живота. Реч градус у значењу степен се може повезати и са Градусовим постепеним кретањем кроз простор и време - из Зембле он путује у Париз, Женеву, Ницу, Копенхаген, Њујорк и Њу Вај, при чему се приближава својој жртви. Што је он ближи „нама”, то ми добијамо више (често небитних) информација о њему:

„Белешке које се односе на њега тако сам распоредио да прва (види белешку уз стих 17 где су назначене и неке друге његове активности) буде најнејаснија, док оне које следе постају градуално јасније како се градуални Градус приближава у простору и времену"12 (NABOKOV 1962/1988: 116).

„Градус нам је сада много ближи у простору и времену него што је био

12 У оригиналу: „I have staggered the notes referring to him in such a fashion that the first (see note to line 17 where some of these other activities are adumbrated) is the vaguest while those that follow become gradually clearer as gradual Gradus approaches in space and time." 
у претходним певањима. Он има кратку тршаву црну косу. Празан дугуљаст облик његовог лица можемо попунити већином елемената, као што су густе обрве и брадавице на бради. Има румен али нездрав тен. Видимо, сасвим изоштрено, структуру његових понешто хипнотичких органа вида. Видимо његов меланхолични нос с искривљеним хрбатом и ужлебљеним врхом. Видимо минерално плаветнило његове вилице и шљунковите тачкице сузбијених бркова"13 (NABOKOV 1962/1988: 208).

Сам Кинбот Градуса назива „градуални Градус”, и реч „градуална” (NABOKOV 1962/1988: 60) и „градуално” (NABOKOV 1962/1988: 125) из Шејдове песме везује управо за Градуса, јер то види као његову главну карактеристику. Ово се такође може довести у везу са ауторовим поступком карактеризације ликова којим се постепено - градуално открива суштина једног лика. Природа Набоковљевог романа је, изгледа, управо градуална, што смо ближи крају, то ствари постају јасније, а сенка која пада на догађаје полако нестаје. За Кинбота су процес настајања песме и Градусовог „градуалног” приближавања међусобно повезани:

„Сила која га гони је магично деловање саме Шејдове песме, механизам и замах стихова, моћни јамбски мотор. Никада још није неумитно напредовање судбине добило такав чулни облик (за друге слике приближавања тог трансценденталног пробисвета види белешку уз стих 17)" (NABOKOV 1962/1988: 104).

Остале варијанте презимена овог човека такође имају своја значења. Греј (Gray) и де Греј (de Gray) су везане за енглеску реч gray, чије је основно значење сив, грао боје, а има још неколико значења, од којих су само нека битна за ову анализу: нејасан, безнадежан, тужан, суморан, мрачан, а може означавати безизразну, безличну или анонимну особу. Нешто слично се може наћи и у Кинботовом опису Градуса:

„Гротескна фигура Градуса, мелеза шишмиша и крабе, није била много необичнија од многобројних других Сенки, [...] Обожавао је опште идеје, а чинио је то с цепидлачким самопоуздањем. Општост је била божанска, посебност ђаволска"14 (NABOKOV 1962/1988: 115-117)

13 У оригиналу: „Gradus is now much nearer to us in space and time than he was in the preceding cantos. He has short upright black hair. We can fill in the bleak oblong of his face with most of its elements such as thick eyebrows and a wart on the chin. He has a ruddy but unhealthy complexion. We see, fairly in focus, the structure of his somewhat mesmeric organs of vision. We see his melancholy nose with its crooked ridge and grooved tip. We see the mineral blue of his jaw and the gravelly pointillé of his suppressed mustache."

14 У оригиналу: „The grotesque figure of Gradus, a cross between bat and crab, was not much odder than many other Shadows [...] He worshiped general ideas and did so with pedantic aplomb. The generality was godly, the specific diabolical." 
Речи којима Кинбот описује Градуса показују његову неодређеност, општост, анонимност, слично као и Шејдово презиме које смо већ раније довели у везу са појмом непознатости. Уз то Градус је заиста доносилац сивила, мрака, туге - он је представник смрти, што доказује убиством Џона Шејда. На једном месту у песми Шејд каже: „Све боје чињаху ме срећним, чак и грао” (NABOKOV 1962/1988: 24). Ово звучи веома парадоксално, јер управо неко чије је презиме „грао” односи његов живот.

Преостаје још и псеудоним д’Аргус, који, као код Сибил, везујемо за грчку митологију. Аргус је био див са стотину очију, па је због тога сматран савршеним стражаром, јер би му у сваком тренутку само део очију спавао, а остатак би вешто мотрио на околину. Био је у служби богиње Хере. Један од његових битнијих подвига је било убиство чудовиште Ехидне, мајке многих других чудовишта, које је убио у име богова са Олимпа. Хера је Аргуса одредила да чува Зевсову љубавницу Ио претворену у краву. На Зевсов наговор, бог Хермес је успавао Аргуса и одрубио му главу. Хера је, по легенди, у знак сећања на верност, пренела Аргусове очи на реп пауна, њене свете птице (BIBLIOTEKA PSEUDOAPOLODOR).

Кинботов д’Аргус, Набоковљев Џек Греј, опет је потпуна инверзија митске фигуре Аргуса. Тако д’Аргус није вешти чувар и заштитник, већ неспретни убица. За митског Аргуса, као главну особину, везујемо савршен вид и будност; на другој страни је д’Аргус који очигледно не види баш добро јер успева да убије потпуно погрешну особу - у Кинботовом паралелном свету он Шејда убија уместо краља Зембле, док га у стварном свету убија уместо судије Голдсворта, који га је претходно осудио. Набоков простор на коме се дешава реалистични (ако реалистичним сматрамо Шејдов свет) део радње Бледе ватре назива управо Аркадија. Међутим, то доноси још један парадокс - д’Аргус не ослобађа Аркадију њених мука, већ у њу уноси немир, убиством једном од најбољих њених песника. Кинбот у једном тренутку каже:

„Ко је могао претпоставити да је баш на тај дан (7. јула) када је Шејд записао тај сјактави стих (последњи на његовој двадесет трећој картици) Градус, алијас Дегре, одлетео из Копенхагена за Париз, и тако довршио други скок на свом злокобном путовању! Чак и у Аркадији сам ја, каже Смрт на надгробном натпису"15(NABOKOV 1962/1988: 133).

Мноштво различитих интерпретација и симболичких значења које Набоковљево именовање ликова нуди откривају и његов иронијски поступак којим се читаоци и критичари упућују на широку анализу и

15 У оригиналу: „Who could have guessed that on the very day (July 7) Shade penned this lambent line (the last one on his twentythird card) Gradus, alias Degré, had flown from Copenhagen to Paris, thus completing the second lap of his sinister journey! Even in Arcady am I, says Death in the tombal scripture." 
(поновно) промишљање значења како самог романа тако и свих ликова.

\section{Закључак}

Набоковљева употреба имена је изгледа ништа мање комплексна од осталих елемената његове фикције. Он вешто користи значења и симболику имена како би их уградио у структуру Бледе ватре и, на неки начин, додатно закомпликовао већ ионако довољно комплексан однос стварности и маште и чудне споне паралелних интерпретација света. Чињеница да из скоро сваког имена произилази више од једног значења, и да се свако име може везати за више различитих појединаца, савршено доприноси разграњавању мреже у којој читалац трага за нитима које га приближавају истини. Имена често садрже варке, које могу да нас наведу на погрешне закључке, а каткад воде и до парадокса, поготову онда када имамо у виду положај имена у савременом свету. У овом роману, веома ретко имена имају оно значење које читалац очекује, а веома је тешко рећи да ли су понуђена решења исцрпла сву симболику коју је Набоков желео да у роман угради. У формирању претпоставки, читалац мора да у ономастичким оквирим размишља о семантици, етимологији, митологи-

ји, религији и историји, па чак ни тада не може бити сигуран да је дошао до значења које је Набоков желео да оствари, јер, једноставно, нема обрасца по коме Набоков бира имена. Све је то, међутим, најбоље схватити као Набоковљев позив на игру и на решавање бројних загонетки. Уколико игру именима схватимо на такав начин, можемо још једном да видимо до које мере је Бледа ватра активан роман, такав да захтева потпуно ангажовање у вечитом и неизвесном походу на нешто што би смо могли назвати песничком истином.

Из аналитичке перспективе, ова студија показује и неке од изазова књижевне ономастике и велику сложеност која она може да достигне и са веома малим бројем именованих ликова. Чињеница је да писац само именовање може да користи као додатни симболички слој, или низ симболичких слојева (што је случај са Набоковим), а у таквој ситуацији приступ постаје близак археологији и, као што се могло видети, прожет дозом спекулативног и интерпретативног.

\section{Цитирана литература}

AJHELBERGER 1984: Eichelberger, Carl. "Gaming in the Lexical Playfields of Nabokov's Pale Fire”. Critical Essays on Vladimir Nabokov, edited by Phyllis A. Roth, Boston: C. K. Hall, 1984, 176-185.

BAGBI I SIGALOV 1987: Bagby, Lewis and Pavel Sigalov. "The semiotics of names and naming in Tolstoj's 'The Cossacks"'. The Slavic and East European Journal 31 (1987), 473-489. 
BIBLIOTEKA PSEUDOAPOLODOR: Apollodorus. The Library, with an English Translation by Sir James George Frazer, F.B.A., F.R.S. in 2 Volumes. Cambridge: MA, Harvard University Press; London: William Heinemann Ltd., 1921. <http://www.perseus.tufts.edu/hopper/text?doc=Perseus\%3Atext\%3A1999.01.0022\&redirect=true $>15.5 .2020$.

BOJD 2001: Boyd, Brian, Nabokov's Pale Fire: The Magic of Artistic Discovery, Princeton: Princeton University Press, 2001.

HAF 2016: Hough, Carole. The Oxford Handbook of Names and Naming. Oxford: Oxford University Press, 2016. DOI: https://doi.org/10.1093/oxfordhb/9780199656431.001.0001

HERAKLIT: Heraklit, 12. fragment <http://www.crystalinks.com/sybil.html> 25. 5 . 2008.

KAVIL 2016: Cavill, Paul. "Language-based approaches to names in literature”. The Oxford Handbook of Names and Naming, edited by Carole Hough, Oxford: Oxford University Press, 2016, 355-369. DOI: https://doi.org/10.1093/ oxfordhb/9780199656431.013.15

KING I VILSON 2003: King, Greg, and Wilson, Penny. The Fate of the Romanovs, New Jersey: John Wiley and Sons, Inc., 2003.

KOUTS 2006: Coates, Richard. "Introduction". Onoma 41 (2006): 7-13. DOI: https:// doi.org/10.2143/ONO.41.0.2119607

KRIPKE 1980: Kripke, Saul. Naming and Necessity. Harvard: Harvard University Press, 1980.

MAKARTI 1962: McCarthy, Mary, "A Bolt from the Blue”, The New Republic, $4^{\text {th }}$ June, 1962.

MILENKOVIĆ I MLADENOVIĆ 2016: Milenković, Katarina and Maša Mladenović.

"Name Symbolism in Harry Potter Book Series". Jezik, književnost, značenje - Jezička istraživanja, uredile Biljana Mišić Ilić i Vesna Lopičić. Niš: Filozofski fakultet Univerziteta u Nišu, 2016, 637-649.

NABOKOV 1962/1988: Nabokov, Vladimir, Bleda vatra, prev. sa eng. David Albahari, Narodna knjiga, Beograd, 1962/1988.

OED 2002: Oxford English Dictionary, OED CD Second Edition, Oxford University Press, Oxford, 2002.

PALMER 1976: Palmer, Frank R. Semantics. Cambridge: Cambridge University Press, 1976.

SMIT 2016: Smith, Grant W. “Theoretical foundations of literary onomastics”. The Oxford Handbook of Names and Naming, edited by Carole Hough, Oxford: Oxford University Press, 2016, 295-309. DOI: https://doi.org/10.1093/ oxfordhb/9780199656431.013.41

N.B. Цитате из дела која су у литератури наведена са називом на енглеском језику са енглеског на српски превели су аутори. 
Dušan M. Stamenković

Ana V. Kocić Stanković

\section{MEANING AND SYMBOLISM OF CHARACTER NAMES IN PALE FIRE}

The paper is an attempt to offer a reading of Vladimir Nabokov's Pale Fire in light of literary onomastics with a special emphasis on characters' names and naming. The theoretical framework is based on various subdisciplines of onomastics, its chronology and, especially, the development of literary onomastics and its insights. As this is a rather novel academic area of interest, this is an attempt of integrating this framework of analysis into the reading of a well-known novel. The paper analyzes the names of four major characters in the novel and their mythological, semiotic, symbolical and ironic components and possible interpretations. One of the key hypotheses is that the meanings of both the novel and individual characters and their names is construed in the interaction of various symbolical meanings and implications, i.e. through an interplay of poetic truth and fiction. It can be concluded that Nabokov's major strength as a writer lies in his use of meanings and symbolism of names which make the structure of the novel as complex as a relationship between truth and fiction both in the world of the novel and its various interpretations and in the material world around us.

Key words: onomastics, naming, name, surname, Nabokov, Pale Fire 